\title{
Gambaran Bakteri pada Kran Air dan Tombol Flush Kloset Duduk di Toilet Umum Lingkungan Fakultas Kedokteran Universitas Andalas Tahun 2018
}

Ria Maryanti ${ }^{1}$, Netti Suharti², Arni Amir ${ }^{3}$

\begin{abstract}
Abstrak
Kran air dan tombol flush kloset merupakan kelengkapan toilet umum dan sering digunakan masyarakat. Penggunaan toilet umum terutama kran air dan tombol flush kloset yang bergantian oleh masyarakat dapat menjadi media tempat hidup bakteri dan penularan penyakit, tetapi menjadi terabaikan oleh masyarakat. Penelitian ini bertujuan untuk mengetahui gambaran bakteri pada kran air dan tombol flush kloset di toilet umum Fakultas Kedokteran Universitas Andalas tahun 2018. Penelitian ini merupakan penelitian deskriptif yang dilaksanakan pada bulan Juli $2017-$ April 2018. Populasi penelitian adalah toilet umum di Fakultas Kedokteran Universitas Andalas. Sampel penelitian adalah bagian dari populasi yang memenuhi kriteria inklusi dan tidak eksklusi. Analisis pada 48 sampel, didapatkan bakteri pada kran air adalah Bacillus sp. 18 isolat, E.coli 2 isolat, Klebsiella sp. 2 isolat, dan S. aureus 2 isolat. Bakteri pada tombol flush kloset adalah Bacillus sp. 14 isolat, E. coli 4 isolat, Klebsiella sp. 2 isolat, S. aureus 3 isolat, dan $P$. aeruginosa 1 isolat. Pada penelitian ini disimpulkan bakteri yang ditemukan adalah Bacillus sp. sebanyak 32 (66,67\%), E. coli $6(12,50 \%)$, S. aureus $5(10,42 \%)$, Klebsiella sp.4 (8,33\%), dan P. aeruginosas $1(2,08 \%)$. Oleh karena itu, bagi pengguna toilet diharapkan mencuci tangan menggunakan air dan sabun, sedangkan bagi petugas kebersihan diharapkan membersihkan kran air dan tombol flush kloset.
\end{abstract}

Kata kunci: kran air, tombol flush kloset, bakteri

\section{Abstract}

The water faucet and toilet flush button are included in the completeness of public toilets and most frequently used by public. The use of public toilets, especially water faucet and toilet flush button by the community can be a medium for living bacteria and become disease transmission, but it is neglected by the community. This research aims to determine the description of bacteria on the water faucet and toilet flush button in public toilets at the Faculty of Medicine Andalas University in 2018. A descriptive study was done in July 2017-April 2018. The population are public toilets at the Faculty of Medicine Andalas University. The sample is part of the population that meets the inclusion and not exclusion criteria. Analysis of 48 samples, found the bacteria on water faucet are Bacillus sp. in 18 isolates, E. coli in 2 isolates, Klebsiella sp. in 2 isolates, and S.aureus in 2 isolates. Bacteria found on toilet flush button are Bacillus sp. in 14 isolates, Klebsiella sp. in 2 isolates, S. aureus in 3 isolates, and P. aeruginosa in 1 isolate. In this study can be concluded that bacteria found are Bacillus sp. as many as 32 (66.67\%), E. coli 6 (12.50\%), S. aureus 5 (10.42\%), Klebsiella sp. 4 (8.33\%), and P. aeruginosa 1 (2.08\%). Therefore, for toilet users are expected to use water and soap for hand washing, while for the janitor is expected to clean the water faucet and toilet flush button.

Keywords: water faucet, toilet flush button, bacteria.

Affiliasi penulis: 1. Prodi Pendidikan Dokter Fakultas Kedokteran Universitas Andalas Padang (FK Unand), 2. Bagian Mikrobiologi FK Unand, 3. Bagian Biologi FK Unand

Korespondensi: Ria Maryanti, Email: riamaryanti969@gmail.com, Telp: 085263199665

\section{PENDAHULUAN}

Penularan penyakit dipengaruhi oleh banyak peran, salah satunya adalah benda tak hidup atau dikenal dengan fomite. Peran fomite dalam penularan penyakit adalah melalui benda mati atau tak hidup yang telah terkontaminasi dengan organisme penyebab 
penyakit yang selanjutnya disentuh oleh orang lain. ${ }^{1}$ Kejadian penyakit pertama kali dikemukakan oleh Hipocrates (460-377 SM), pada karyanya yang berjudul Airs, Water and Places, ia mematahkan penjelasan supernatural tentang terjadinya penyakit dan menyatakan bahwa penyakit timbul karena berbagai hal seperti iklim, tanah, air, mode kehidupan, dan nutrisi di sekitar manusia. ${ }^{2}$ Perluasan jaringan transportasi global mengakibatkan penularan penyakit berpindah lebih jauh, lebih cepat, dan dalam jumlah yang besar. ${ }^{3}$ Kejadian dan penularan penyakit dapat disebabkan oleh beberapa faktor seperti, faktor predisposisi, faktor penyebab, dan faktor lingkungan. Salah satu faktor penyebab yang penting adalah agen yang dapat berupa unsur hidup seperti virus, bakteri, jamur, dan unsur mati berupa unsur fisika, kimia, serta fisik. ${ }^{4} \quad$ Manusia mengenal penularan banyak penyakit dari berbagai hal, baik secara langsung maupun tidak langsung, tentu dengan banyaknya penyakit yang dapat menyerang manusia, membuat mereka lebih sadar lagi untuk melakukan pencegahannya, tetapi ada cara penularan penyakit yang tidak begitu populer di masyarakat, seperti di lingkungan dalam rumah atau public restroom yang umumnya dikenal dengan toilet. ${ }^{5}$ Toilet adalah fasilitas sanitasi untuk tempat buang air besar dan kecil, tempat cuci tangan dan muka, sedangkan toilet umum adalah sebuah ruangan yang bersih, aman, nyaman dan higienis yang dirancang khusus lengkap dengan kloset, persediaan air bersih dan perlengkapan lainnya, dimana masyarakat luas pada saat di tempat - tempat domestik, komersial maupun publik dapat membuang hajat serta memenuhi kebutuhan fisik maupun sosial dan psikologis lainnya. ${ }^{6}$ Public restroom atau toilet merupakan tempat yang berisiko untuk menularkan penyakit, seperti melalui fekal oral atau yang lainnya, oleh karena toilet digunakan oleh banyak orang. ${ }^{7}$ Enteropatogen atau patogen yang biasa ditemukan pada kulit manusia seperti Staphylococcus aureus, dapat dengan mudah ditransmisikan antar individu dengan menyentuh permukaan public restroom. ${ }^{8}$ Data dari World Toilet Organization (WTO) pada tahun 2013 menyebutkan 1000 anak meninggal setiap harinya karena diare yang disebabkan karena buruknya sanitasi, satu dari tiga orang di bumi masih belum memiliki akses toilet yang bersih dan aman, dan sanitasi yang baik tentunya mendukung nutrisi dan kesehatan yang lebih baik, terutama bagi wanita dan anak-anak. ${ }^{9}$ Data dari Kemenkes RI tahun 2016 menunjukkan penemuan kasus diare di provinsi Sumatera Barat sebanyak 140.300 kasus dengan persentase diare yang ditangani sebanyak $25,9 \% .{ }^{10}$ Diare juga termasuk ke dalam sepuluh penyakit terbanyak di Kota Padang tahun 2015 dengan jumlah kasus sebanyak 9.616 kasus dimana jumlah ini naik dari tahun sebelumnya yang berjumlah 7.827 kasus. ${ }^{11}$

Penelitian yang dilakukan oleh Mkrtchyan pada tahun 2013, terdapat beberapa jenis bakteri yang biasanya ditemukan di toilet yaitu dari Family Staphylococcaceae terdapat 103 dari 211 sampel, Bacillaceae terdapat 37 dari 211 sampel, Micrococcaceae terdapat 30 dari 211 sampel, dan Enterobacteriaceae terdapat 7 dari 211 sampel. ${ }^{12}$ Penelitian lain yang dilakukan di Taif pada 20 toilet umum wanita juga menunjukkan keberadaan beberapa jenis bakteri yang biasanya ditemukan di toilet yaitu Staphylococcus aureus 30,1\%, Klebsiella pneumonia 25,7\%, E. coli 16\%, , Enterobacter spp. 11,2\%, Citrobacter spp. 7,1\%, Pseudomonas aeruginosa 5,9\%, dan Proteus spp. 4,5\%. ${ }^{13}$ Penelitian lain juga dilakukan oleh Gilberto E. Flores pada tahun 2010 di Universitas Colorado di kampus Boulder, dimana sampel yang digunakan adalah 12 toilet yang terdiri dari enam toilet pria dan enam toilet wanita. Hasil penelitian tersebut menunjukkan bahwa bakteri yang banyak terdapat pada kran antara lain Propionibacteriaceae, Corynebacteriaceae, Micrococcaceae, Staphylococcaceae, dan Streptococcaceae. Bakteri yang banyak terdapat pada tombol toilet antara lain Propionibacteriaceae, Corynebacteriaceae, Lactobacillaceae, Provotellaceae, dan Clostridiales. ${ }^{8}$ Keberadaan bakteri di toilet seperti pada kran air dan tombol flush kloset bisa menimbulkan penyakit salmonellosis dan mengalami diare yang disebabkan oleh bakteri Salmonella dari famili Enterobacteriaceae. ${ }^{14} \quad$ Penemuan bakteri di toilet berdasarkan penelitian-penelitian tersebut telah menjadi bukti bahwa perlu diperhatikan lagi tentang kebersihan diri setiap individu dalam menggunakan toilet dan sistem pembersihan yang sudah dilakukan petugas di toilet. Bakteri bisa menetap dan tumbuh di toilet dalam waktu yang lama meskipun telah disiram atau dibersihkan dengan cairan anti-mikroba. Faktor 
lain yang juga berpengaruh yaitu individu yang memiliki imunitas terganggu akan lebih mudah terkena penyakit, karena toilet umum merupakan salah satu tempat yang berisiko untuk penularan penyakit. ${ }^{13}$

Higiene dan sanitasi dari pengguna toilet maupun petugas kebersihan diperlukan untuk menangani kasus-kasus tersebut. Higiene adalah ilmu pengetahuan yang mempelajari kesehatan dan lebih banyak membahas masalah bakteri sebagai penyebab timbulnya penyakit. Sanitasi merupakan usaha untuk mengawasi dan memperhatikan faktor lingkungan fisik yang berpengaruh terhadap manusia, terutama hal-hal yang mempunyai efek merusak perkembangan fisik, kesehatan, dan kelangsungan hidup. Higiene dan sanitasi memiliki pengertian dan tujuan yang sama yaitu untuk mencapai kesehatan yang prima. ${ }^{15}$ Berdasarkan uraian di atas, harus kita waspadai bahwa bahaya penularan penyakit bisa terjadi lewat siapa saja, apa saja, kapan saja, dan dimana saja. Kejadian penularan penyakit yang belum diketahui di lingkungan Fakultas Kedokteran Universitas Andalas khususnya melalui kran dan tombol kloset juga merupakan faktor lain yang perlu diperhatikan. Berdasaran survei di lapangan, ditemukan bahwa toilet umum di lingkungan Fakultas Kedokteran Universitas Andalas tidak memiliki kelengkapan toilet yang memadai, seperti tidak disediakannya tisu toilet dan sabun untuk mencuci tangan sebagai salah satu sarana untuk pencegahan infeksi. Wawancara yang dilakukan dengan petugas kebersihan toilet umum lingkungan Fakultas Kedokteran Universitas Andalas menunjukkan bahwa masih minimnya kebersihan toilet karena petugas hanya membersihkan area kotor yang tampak tanpa membersihkan area kran dan tombol flush kloset. Wawancara yang dilakukan dengan pengguna toilet memperlihatkan minimnya kesadaran pengguna toilet dalam menjaga kebersihan karena tidak menggunakan alas saat menggunakan kran air dan tombol flush kloset serta tidak mencuci tangan setelah menggunakan toilet. Oleh karena itu peneliti ingin mencari tahu apa saja bakteri yang terdapat pada kran air dan tombol flush kloset duduk di toilet umum di lingkungan Fakultas Kedokteran Universitas Andalas yang ramai dikunjungi oleh civitas akademik yang memungkinkan terjadinya kontak antara satu orang dengan yang lainnya.

\section{METODE}

Penelitian ini merupakan penelitian jenis deskriptif dengan desain cross-sectional yang dilaksanakan pada bulan Juli 2017 hingga April 2018 di toilet umum Fakultas Kedokteran Universitas Andalas. Populasi penelitian adalah toilet umum di lingkungan Fakultas Kedokteran Universitas Andalas. Sampel penelitian adalah bagian dari populasi yang memenuhi kriteria inklusi dan tidak eksklusi. Kriteria inklusi penelitian ini adalah toilet umum berupa kloset duduk yang memiliki kran air dan tombol flush kloset di Lingkungan Fakultas Kedokteran Universitas Andalas. Kriteria eksklusi adalah toilet yang tidak digunakan serta toilet yang kran air dan tombol flush kloset yang rusak. Penelitian ini dilakukan dengan teknik swab, kemudian hasilnya dikultur, dan selanjutnya dilihat gambaran bakteri yang tumbuh.

HASIL

Tabel 1. Hasil pewarnaan Gram

\begin{tabular}{lcccc}
\hline & \multicolumn{2}{c}{ Kran Air } & \multicolumn{2}{c}{$\begin{array}{l}\text { Tombol Flush } \\
\text { Kloset Duduk }\end{array}$} \\
\cline { 2 - 5 } Bakteri & $\begin{array}{l}\text { Frekuen } \\
\text { si (n) }\end{array}$ & $\begin{array}{l}\text { Persenta } \\
\text { se (\%) }\end{array}$ & $\begin{array}{l}\text { Frekue } \\
\text { nsi (n) }\end{array}$ & $\begin{array}{l}\text { Perse } \\
\text { ntase } \\
(\%)\end{array}$ \\
\hline $\begin{array}{l}\text { Gram } \\
\text { positif (+) }\end{array}$ & 20 & 83 & 17 & 71 \\
$\begin{array}{l}\text { Gram } \\
\text { negatif (-) }\end{array}$ & 4 & 17 & 7 & 29 \\
\hline Jumlah & $\mathbf{2 4}$ & $\mathbf{1 0 0}$ & $\mathbf{2 4}$ & $\mathbf{1 0 0}$ \\
\hline
\end{tabular}

Tabel 1 menunjukkan hasil pewarnaan Gram pada hasil kultur dari kran air didapati lebih banyak bakteri Gram positif dibandingkan bakteri Gram negatif. Begitu juga dengan bakteri yang didapati pada tombol flush kloset duduk lebih banyak bakteri Gram positif dibandingkan bakteri Gram negatif.

Tabel 2. menunjukkan hasil uji bikomia pada bakteri Gram negatif berupa uji TSIA, uji Simon Sitrat, dan uji semi solid. Pada uji bikokimia, didapati bakteri Escherichia coli pada kran air dan tombol flush kloset duduk. Bakteri lain yang ditemukan pada kran air adalah Staphylococcus aureus dan Klebsiella $s p$. Sedangakan pada tombol flush kloset duduk ditemukan Staphylococcus aureus, Pseudomonas aeruginosa, dan Klebsiella sp. Bakteri yang paling banyak didapati pada kran air adalah Bacillus sp. diikuti E. coli, S. aureus, dan Klebsiella sp. Bakteri yang paling banyak pada tombol flush kloset adalah Bacillus sp, diikuti E.coli, S, aureus, Klebsiella sp. dan Pseudomonas aeruginosa. 
Tabel 2. Bakteri ada identifikasi biokimia

\begin{tabular}{lcccc}
\hline & \multicolumn{2}{c}{ Kran } & \multicolumn{2}{c}{$\begin{array}{l}\text { Tombol Flush } \\
\text { Kloset Duduk }\end{array}$} \\
\cline { 2 - 5 } Bakteri & $\begin{array}{l}\text { Frekue } \\
\text { nsi (n) }\end{array}$ & $\begin{array}{l}\text { Persent } \\
\text { ase (\%) }\end{array}$ & $\begin{array}{l}\text { Frekue } \\
\text { nsi (n) }\end{array}$ & $\begin{array}{l}\text { Persent } \\
\text { ase (\%) }\end{array}$ \\
\hline $\begin{array}{l}\text { Bacillus } \\
\text { sp. }\end{array}$ & 18 & 76 & 14 & 58 \\
$\begin{array}{l}\text { E. coli } \\
\text { Klebsiella }\end{array}$ & 2 & 8 & 4 & 17 \\
sp. & 2 & 8 & 2 & 8 \\
$\begin{array}{l}\text { S. aureus } \\
\text { P. }\end{array}$ & 2 & 8 & 3 & 13 \\
$\begin{array}{l}\text { aeruginos } \\
\text { a }\end{array}$ & 0 & 0 & 1 & 4 \\
\hline Jumlah & & & & \\
\hline
\end{tabular}

Tabel 3. Jenis bakteri menurut sifat bakteri

\begin{tabular}{lcccc}
\hline \multirow{3}{*}{ Bakteri } & \multicolumn{2}{c}{ Kran } & \multicolumn{3}{c}{$\begin{array}{l}\text { Tombol Flush } \\
\text { Kloset Duduk }\end{array}$} \\
\cline { 2 - 6 } & $\begin{array}{l}\text { Freku } \\
\text { ensi } \\
\text { (n) }\end{array}$ & $\begin{array}{l}\text { Perse } \\
\text { ntase } \\
(\%)\end{array}$ & $\begin{array}{l}\text { Freku } \\
\text { ensi } \\
\text { (n) }\end{array}$ & $\begin{array}{l}\text { Persen } \\
\text { tase } \\
(\%)\end{array}$ \\
\hline $\begin{array}{l}\text { Tidak patogen } \\
\text { Berpotensi }\end{array}$ & 18 & 76 & 14 & 58 \\
menjadi & 6 & 24 & 10 & 42 \\
patogen & & & & \\
\hline Jumlah & $\mathbf{2 4}$ & $\mathbf{1 0 0}$ & $\mathbf{2 4}$ & $\mathbf{1 0 0}$ \\
\hline
\end{tabular}

Tabel 3. menunjukkan pengelompokan bakteri berdasarkan sifat patogennya, dimana perentase bateri yang tidak patogen lebih banyak dibanding bakteri yang berpotensi menjadi patogen.

\section{PEMBAHASAN}

Penelitian ini menunjukkan terdapat lebih banyak bakteri Gram positif yaitu sebanyak 37/48 (77,08\%) dibandingkan dengan Gram negatif yaitu sebanyak 11/48 (22,92\%). Hal ini menunjukkan bahwa keberadaan flora normal pada berbagai area kulit berbeda. ${ }^{16}$ Area kulit yang relatif lembab seperti ketiak dan perineum lebih didominasi oleh bakteri Gram negatif dibandingkan dengan area kulit yang lebih kering seperti tangan dan kaki yang didominasi Gram positif. ${ }^{16}$ Hal ini sesuai dengan penelitian yang dilakukan Sabra di Taif pada tahun 2013 yang mendapati bakteri Gram positif lebih banyak daripada Gram negatif. ${ }^{13}$

Berdasarkan keseluruhan uji biokimia yang dilakukan, terdapat bakteri Bacillus sp., E. coli, Klebsiella sp., S. aureus, dan Pseudomonas aeruginosa. Bacillus sp. merupakan Famili Bacillaceae dan S. aureus merupakan Famili Staphylococcaceae, dimana kedua bakteri tersebut berasal dari Filum Firmicutes. ${ }^{17} \mathrm{~S}$. aureus yang memiliki daya invasi rendah menyebabkan infeksi kulit seperti jerawat, pioderma atau impetigo. ${ }^{17}$ Penyakit lain yang disebabkan karena $S$. aureus yaitu pneumonia, meningitis, empiema, endokarditis, atau sepsis. ${ }^{17} \mathrm{E}$. coli dan Klebsiella sp. merupakan Famili Enterobacteriaceae, sedangkan $P$. aeruginosa merupakan Famili Pseudomonadaceae, ketiga bakteri tersebut berasal dari Filum Proteobacteria. ${ }^{17}$ E. coli dan Klebsiella sp. menjadi patogen jika berada pada jaringan di luar usus tempat biasanya bakteri ini dtemukan atau tempat lain yang jarang ditempati bakteri ini. ${ }^{17}$ Biasanya infeksi karena kedua jenis bakteri tersebut terjadi pada saluran kemih, saluran empedu, dan tempat lain dalam rongga abdomen. ${ }^{17}$ Bakteri $P$. aeruginosa menjadi patogenik jika mencapai daerah yang tidak memiliki pertahanan normal, seperti membran mukosa dan kulit yang terluka oleh cedera jaringan langsung pada penggunaan kateter urin atau intravena. ${ }^{17}$ Bakteri yang berasal dari filum Firmicutes dan Proteobacteria merupakan bakteri yang umum ditemukan di lingkungan dalam ruangan, salah satunya public restroom atau toilet. ${ }^{18}$ Penemuan Filum Firmicutes dan Proteobacteria pada penelitian ini sama dengan penelitian yang dilakukan oleh Gilberto E. Flores pada tahun 2010 di Universitas Colorado. ${ }^{8}$ Filum lain yang ditemukan oleh Gilberto E. Flores adalah Actinobacteria yang salah satu Familinya adalah Propionibacteriaceae. ${ }^{8}$ Filum tersebut tidak ditemukan pada penelitian ini. Hal ini karena ada berbagai faktor yang mempengaruhi keberadaan flora normal pada kulit, seperti kelembaban, suhu tubuh, dan konsentrasi lipid permukaan kulit. ${ }^{16}$ Faktor lain yang mempengaruhi adalah keseimbangan antara kondisi individu dengan keberadaan mikroorganisme, baik yang bersifat endogen seperti variasi genetik yang memilih komunitas mikroba tertentu ataupun yang bersifat eksogen seperti personal hygiene, desinfeksi, dan sterilisasi yang dilakukan oleh petugas kebersihan. ${ }^{19}$

Penemuan bakteri Bacillus sp.,

Staphylococcus, dan Enterobacteriacea pada penelitian ini sama dengan penelitian yang dilakukan Mkrtchyan pada tahun 2013. ${ }^{12} \mathrm{Hal}$ itu karena Bacillus $s p$. merupakan bakteri basil Gram positif dan bakteri pembentuk spora yang dapat hidup di lingkungan selama beberapa tahun dan kebanyakan tidak patogen terhadap manusia. ${ }^{17}$ Begitu juga Staphylococcus yang 
merupakan flora normal pada manusia dan ditemukan pada permukan kran air dan tombol flush kloset karena adanya kontak langsung antara area tersebut dengan tangan manusia. ${ }^{17}$ Penemuan bakteri dari Filum Enterobacteriaceae di toilet merupakan hal yang bisa saja terjadi, karena bakteri tersebut merupakan bakteri yang ditemukan pada saluran cerna dan rektum. ${ }^{17}$ Bakteri tersebut bisa ditemukan pada kran air dan tombol flush kloset karena kontaminasi tangan manusia yang tidak bersih setelah BAB ataupun karena percikan aerosol dari kloset duduk. ${ }^{20}$

Bakteri yang paling sedikit ditemukan adalah Pseudomonas aeruginosa sebanyak 4\%. Pseudomonas aeruginosa merupakan batang Gram negatif yang tersebar luas di alam dan merupakan flora normal usus dan kulit dalam jumlah kecil. ${ }^{17} P$. aeruginosa bersifat invasif dan toksigenik serta menyebabkan infeksi pada pasien dengan daya tahan tubuh yang abnormal. ${ }^{17} P$. aeruginosa hanya bersifat patogenik jika terpajan pada daerah yang tidak terdapat pertahanan tubuh normal, seperti membran mukosa dan kulit yang rusak akibat kerusakan jaringan langsung. ${ }^{17}$ Keberadaan bakteri ini pada tombol flush kloset disebabkan karena adanya individu yang mentransmisikan bakteri tersebut pada permukaan tombol flush kloset. ${ }^{3} \mathrm{Hal}$ ini sama dengan penelitian yang dilakukan di Taif pada tahun 2013 oleh Sabra yang juga menemukan Pseudomonas aeruginosa sebanyak $5,9 \% .{ }^{13}$

Jenis bakteri yang ditemukan pada kran air dan tombol flush kloset di toilet umum Fakultas Kedokteran Universitas Andalas menujukkan perbedaan yang tidak signifikan. Sementara dari jenis bakteri menurut sifat patogennya, lebih banyak ditemukan bakteri yang bersifat komensal yaitu bakteri yang tidak bersifat merugikan atau non patogen bagi manusia, seperti Bacillus sp., E. coli, dan S. aureus yang ditransmisikan melalui kontak langsung tangan manusia dengan permukaan kran air dan tombol flush kloset. Jenis bakteri lain yang ditemukan yaitu bakteri yang bersifat oportunistik atau bakteri yang bisaanya menyebabkan penyakit jika sistem imun yang tertekan, seperti Klebsiella sp. dan Pseudomonas aeruginosa.

\section{SIMPULAN}

Bakteri yang tedapat pada kran air di toilet umum Fakultas Kedokteran Universitas Andalas adalah
Bacillus sp., E. coli, Klebsiella sp., dan S. aureus. Bakteri yang terdapat pada tombol flush kloset duduk di toilet umum Fakultas Kedokteran Universitas Andalas adalah Bacillus sp., E. coli, S. aureus, Klebsiella sp., dan $P$. aeruginosa.

\section{DAFTAR PUSTAKA}

1. Efendi F, Makhfudli. Keperawatan kesehatan komunitas: teori dan praktik dalam keperawatan. Jakarta: Salemba Medika; 2009. hlm. 51-52.

2. Nelson KE, Williams CM. Infectious disease epidemiology theory and practice. 3rd ed. United States: Jones \& Bartlett Learning; 2014. Hal.3-5.

3. Tatem AJ, Rogers DJ, Hay SI. Global transport networks and infectious disease spread. advances in parasitology. 2006; 62:293-300.

4. Budiarto E, Anggraeni D. Pengantar epidemiologi. Ed 2. Jakarta: Buku Kedokteran EGC; 2003. Hal.3-5.

5. Colijn C, Gardy J. Phylogenetic tree shapes resolve disease transmission patterns. Evolution, Medicine \& Public Health. 2014; 2014(1):96-108.

6. Perpustakaan Kementerian Pekerjaan Umum dan Perumahan Rakyat. Standar toilet umum di Indonesia; 2017 (diunduh November 2017). Tersedia dari: http://pustaka.pu.go.id/?q=content/standar-toiletumum-indonesia

7. Asosiasi Toilet Indonesia. Pedoman standar toilet umum Indonesia. Jakarta: Asosiasi Toilet Indonesia; 2016. Hal.3-5.

8. Flores GE, Bates ST, Knights D, Lauber CL, Stombaugh J, Knight R, et al. Microbial biogeography of public restroom surfaces. Plos One. 2011; 6(11):e28132.

9. World Toilet Organization. What we do. Why toilets? WTO; 2013. (diunduh November 2017) Tersedia dari: http://worldtoilet.org/what-wedo/why-toilets/

10. Kementerian Kesehatan Republik Indonesia. Profil kesehatan Indonesia 2016. Jakarta: Pusat Data dan Informasi Kemenkes Rl; 2017. Hal.87.

11. Dinas Kesehatan Kota Padang. Profil kesehatan kota Padang tahun 2015. Padang: Dinkes Kota Padang; 2016. Hal.87. 
12. Mkrtchyan HV, Russell CA, Wang N, Cutler RR. Could public restrooms be an environment for bacterial resistomes?. Plos One. 2013;8(1):e54223.

13. Sabra SMM. Bacterial public health hazard in the public female restrooms at Taif, KSA. Middle-East Journal of Scientific Research. 2013; 14(1):63-68.

14. Barker J, Bloomfield SF. Survival of Salmonella in bathrooms and toilets in domestic homes following salmonellosis. Journal of Applied Microbiology. 2000; 89:137-144.

15. Kustini H. General hotel management. Yogyakarta: Deepublish; 2017. Hal.32-33.

16. NCBI. Bookshelf. Medical microbiology. Chapter 6 normal flora. 1996 (diunduh November 2017) Tersedia dari: https://www.ncbi.nlm.nih.gov/books/NBK7617

17. Brooks GF, Carroll KC, Butel JS, Morse SA, Mietzer TA. Jawetz medical microbiology. Edisi ke-25. The McGraw-Hill Companies; 2010. Hal.173-242.

18. Rintala H, Pitkaranta M, Toivola M, Paulin L, Nevalainen A. Diversity and seasonal dynamics of bacterial community in indoor environment. BMC Microbiology. 2008; 8:56.

19. Grice EA, Segre JA. The skin microbiome. Nat Rev Microbiology. 2011; 9(4):244-253.

20. Gralton J, Tovey E, McLaws ML, Rawlinson WD. The role of particle size in aerosolised pathogen transmission: A review. Journal of Infection. 2011; 62(1):1-13. 